\title{
Resistance levels to two strains of Potato virus $Y$ (PVY) in transgenic potatoes cv. Achat.
}

\author{
André N. Dusi; César Carvalho; Antônio Carlos Torres; Antonio Carlos de Ávila \\ Embrapa Hortaliças, P. O. Box 218, 70.359-970 Brasília - DF, Brazil; Email: dusi@cnph.embrapa.br
}

\begin{abstract}
Two transgenic potato clones of cv. Achat, denominated $1 \mathrm{P}$ and $63 \mathrm{P}$ were challenged with two Potato virus $Y$ strains $\left(\mathrm{PVY}^{\mathrm{O}}\right.$ and $\left.P V Y^{\mathrm{N}}\right)$, under greenhouse conditions, to be evaluated for resistance to these strains. Optical density values of the Elisa readings of samples from the transgenic plants were compared to readings from samples of the inoculated non-transformed plants. Clone 1P was extremely resistant to both PVY strains, reflected by not being systemically infected. Clone 63P, however, presented partial resistance to both PVY strains as local or systemic infection was delayed in some days. These results confirm the previously reported extreme resistance to PVY of clone 1P.
\end{abstract}

Keywords: Solanum tuberosum, GMO, extreme resistance.

\section{RESUMO}

\section{Achat.}

Dois clones transgênicos de batata, derivados da cv. Achat, denominados $1 \mathrm{P}$ e 63P foram desafiados com duas estirpes do Potato virus $Y\left(\mathrm{PVY}^{\mathrm{O}} \mathrm{PVY}^{\mathrm{N}}\right)$, em condições de casa-de-vegetação, para avaliação do nível de resistência dos clones ao vírus. Os valores de densidade óptica das leituras dos testes de Elisa foram comparados a leituras dos clones não transformados e inoculados. $\mathrm{O}$ clone $1 \mathrm{P}$ apresentou extrema resistência a ambas as estirpes, não tendo sido observada infecção sistêmica nos dois ensaios. O Clone 63P apresentou resistência parcial às duas estirpes, refletida no retardo do aparecimento de infecções sistêmicas por duas semanas. Os resultados obtidos confirmam o alto nível de resistência do clone 1P, relatado anteriormente.

\section{(Aceito para publicação em 6 de setembro de 2.001)}

E xpression of coat protein gene in transgenic dicotyledoneus plants provides an effective protection for more than 20 plant viruses (Hull \& Davies, 1992). And, in recent years, potato became one of the premier targets for plant molecular genetics (Vayda \& Belknap, 1992).

One of the serious problems in potato production is the infection of the crop by Potato virus $Y$ (PVY). Under field conditions, this disease is aphid transmitted in a non-persistent manner. The introduction and expression of coat protein $(\mathrm{CP})$ gene from $\mathrm{PVY}$ in this species by genetic transformation is a viable strategy for protection against this viral infection (Romano et al., 2001).

Several procedures have been used to evaluate both resistance to infection and the mechanism of resistance to a particular virus, including: 1) evaluation of the efficacy of virus inoculation by mechanical and aphids means; 2) quantification of virus concentration in the plant and its correlation with the phenological stage of the plant and 3) yield comparison of infected and non- infected plants (Centro Internacional de la Papa, 1990).

This paper reports the results of greenhouse tests to determine virus resistance in two transgenic potato clones transformed with the coat protein gene of PVY (Romano et al., 2001).

\section{MATERIAL AND METHODS}

Two transgenic potato clones (1P and 63P) (Romano et al., 2001) transformed via Agrobaterium tumefaciens, containing the coat protein gene (CP), and a non-transformed clone cv. Achat were challenged with two PVY strains to evaluate their resistance to these viruses.

Both Brazilian PVYO and PVY ${ }^{\mathrm{N}}$ strains (Nagata et al., 2001) were maintained in potato (Solanum tuberosum ssp tuberosum) and tobacco (Nicotiana tabacum TNN) plants growing under greenhouse conditions.

Tubers from virus free plants of those clones were potted in 5 liter pots. The experiment had a random design with five replications. Only one stem per plant was allowed to grow. Three weeks old growing plants were mechanically inoculated in a basal leaf. Inoculation was repeated after $48 \mathrm{~h}$. Inocula were produced in TNN tobacco plants and diluted 1:20 (w/v) in inoculation buffer (50 mM phosphate buffer $\mathrm{pH} 7.2$ with addition of $1 \%$ sodium sulfite). The inoculated leaves were tagged to record its position in the plant. Bufferinoculated plants (controls) were maintained for each clone. Two independent experiments were established, one for each virus strains.

Samples from both inoculated (basal) and apical leaves of all plants were collected at 15, 30 and 50 days after inoculation (DAI). Leaf disks of $10 \mathrm{~mm}$ diameter were collected per sample. At each sampling, the plants were observed for visual symptoms of infection. The samples were individually weighted and placed in a $1.5 \mathrm{ml}$ microtube with $1: 10(\mathrm{w} / \mathrm{v})$ of extraction buffer and tested by DASElisa (Clark \& Adams, 1977). Only absolute readings were considered. Threshold levels to determine infection 
Table 1. Analysis of variance for the means of the Elisa readings (O.D. $405 \mathrm{~nm}$ ) of the plants inoculated with PVY ${ }^{\circ}$. Values in columns followed by the same letter did not differ statistically by the Tukey’s test. Brasília, Embrapa Hortaliças, 2.001.

\begin{tabular}{lcccccc}
\hline \multirow{2}{*}{ Clone } & \multicolumn{3}{c}{ Inoculated leaf } & \multicolumn{3}{c}{ Apical leaf } \\
\cline { 2 - 7 } & $\mathbf{1 5}$ & $\mathbf{3 0}$ & $\mathbf{5 0}$ & $\mathbf{1 5}$ & $\mathbf{3 0}$ & $\mathbf{5 0}$ \\
\hline $1 \mathrm{P}+$ & $0.089 \mathrm{a}$ & $0.315 \mathrm{~b}$ & $0.103 \mathrm{a}$ & $0.091 \mathrm{a}$ & $0.120 \mathrm{~b}$ & $0.103 \mathrm{a}$ \\
$63 \mathrm{P}+$ & $0.194 \mathrm{~b}$ & $0.421 \mathrm{~b}$ & $0.407 \mathrm{~b}$ & $0.093 \mathrm{a}$ & $0.467 \mathrm{c}$ & $0.895 \mathrm{c}$ \\
Achat + & $0.390 \mathrm{c}$ & $0.471 \mathrm{~b}$ & $0.376 \mathrm{~b}$ & $0.179 \mathrm{~b}$ & $0.505 \mathrm{c}$ & $0.757 \mathrm{c}$ \\
$1 \mathrm{P}-$ & $0.088 \mathrm{a}$ & $0.101 \mathrm{a}$ & $0.102 \mathrm{a}$ & $0.089 \mathrm{a}$ & $0.099 \mathrm{a}$ & $0.098 \mathrm{a}$ \\
$63 \mathrm{P}-$ & $0.094 \mathrm{a}$ & $0.097 \mathrm{a}$ & $0.109 \mathrm{a}$ & $0.092 \mathrm{a}$ & $0.105 \mathrm{ab}$ & $0.119 \mathrm{~b}$ \\
Achat - & $0.093 \mathrm{a}$ & $0.126 \mathrm{a}$ & $0.102 \mathrm{a}$ & $0.091 \mathrm{a}$ & $0.096 \mathrm{a}$ & $0.105 \mathrm{a}$ \\
$\mathrm{P}$ value & $<0.001$ & $<0.001$ & $<0.001$ & $<0.001$ & $<0.001$ & $<0.001$ \\
\hline
\end{tabular}

${ }^{1}(+)$, inoculated plants; (-), buffer-inoculated plants.

Table 2. Analysis of variance for the means of the Elisa readings (O.D. $405 \mathrm{~nm}$ ) of the plants inoculated with PVYN . Values in columns followed by the same letter did not differ statistically by the Tukey’s test. Brasília, Embrapa Hortaliças, 2.001.

\begin{tabular}{|c|c|c|c|c|c|c|}
\hline \multirow{2}{*}{ Clone } & \multicolumn{3}{|c|}{ Inoculated leaf } & \multicolumn{3}{|c|}{ Apical leaf } \\
\hline & 15 & 30 & 50 & 15 & 30 & 50 \\
\hline $1 \mathrm{P}+$ & $0.185 b$ & $0.117 a$ & $0.110 a$ & $0.097 a$ & $0.103 a$ & $0.101 a$ \\
\hline $63 P+$ & $0.351 \mathrm{c}$ & $0.546 \mathrm{~b}$ & $0.914 b$ & $0.119 b$ & $0.819 b$ & $1.041 b$ \\
\hline Achat + & $0.549 \mathrm{c}$ & $0.844 \mathrm{c}$ & $0.944 b$ & $0.649 c$ & $0.960 \mathrm{~b}$ & $0.946 b$ \\
\hline $1 P-$ & $0.108 a$ & $0.113 a$ & $0.105 a$ & $0.097 a$ & $0.105 a$ & $0.099 a$ \\
\hline $63 P$ & $0.099 a$ & $0.107 a$ & $0.102 a$ & $0.095 a$ & $0.109 a$ & $0.098 a$ \\
\hline Achat - & $0.096 a$ & $0.106 a$ & $0.101 a$ & $0.097 a$ & $0.107 a$ & $0.101 a$ \\
\hline$P$ value & $<0.001$ & $<0.001$ & $<0.001$ & $<0.001$ & $<0.001$ & $<0.001$ \\
\hline
\end{tabular}

${ }^{1}(+)$, inoculated plants; (-), buffer-inoculated plants.

were established according to Wijkamp (1995), where samples were considered infected (y) if the optical density at 405 $\mathrm{nm}$ (OD $405 \mathrm{~nm}$ ) were above the average of the non-infected controls plus three times the standard deviation (Equation 1).The antiserum used in the test was produced at Embrapa Hortaliças (Ávila et al., 1986).

$$
y=\bar{x}+3 * \sigma(\text { equation } 1)
$$

The Elisa readings were submitted to the analysis of variance, for each sampling date, to determine resistance level of the transgenic clones. For analysis purposes, data were transformed for the reciprocal values.

\section{RESULTS AND DISCUSSION}

Plants of the clone 1P did not show visual symptoms of infection during the whole experiment. In contrast, symptoms were observed on the clone
63P inoculated with both the $\mathrm{PVY}^{\mathrm{O}}$ strain at $15 \mathrm{DAI}$ and the $\mathrm{PVY}^{\mathrm{N}}$ strain at 30 DAI.

As can be noticed in Tables 1 and 2 the clone $1 \mathrm{P}$ presented an extreme resistance to both PVY strains. Virus could only be detected in the inoculated leaves, and at very low levels. No systemic infection could be detected by Elisa, as O.D. readings were below the threshold level of the test (Figure 1). Clone 63P showed, however, an increase in virus concentration on the inoculated leaves, which was, in general, similar to the nontransformed "Achat". A delayed systemic infection was detected in the clone 63P when compared to the non-transformed control. At the last evaluation date, however, virus concentration in both 63P and non-transformed "Achat" was equivalent. This indicated that the clone $63 \mathrm{P}$ presented an intermediate resistance level.

Previous studies on southern blot hybridization of these transgenic clones revealed more intense bands observed in clone $1 \mathrm{P}$, when compared with clone $63 \mathrm{P}$, indicating that the number of copies of the introduced genes in line 1P might be higher than in line 63P (Romano et al., 2001). Expression of coat protein gene in transgenic plants has been reported as an effective protection in several plant-virus system (Hull \& Davies, 1992). However, the mechanism eliciting this type of resistance is still unclear. In addition, Lindbo \& Dougherty (1992) disclosed that CPmediated resistance has been reported to induce different degrees of protection. They postulated that protection sometimes results from coat protein mRNA accumulation and is independent of a requirement for coat protein expression, thus implying that the mechanisms inducing resistance could be operating at more than one level. Further investigation will be necessary to determine the relationship between the level of expression of the transgene and the response to viral infection. 


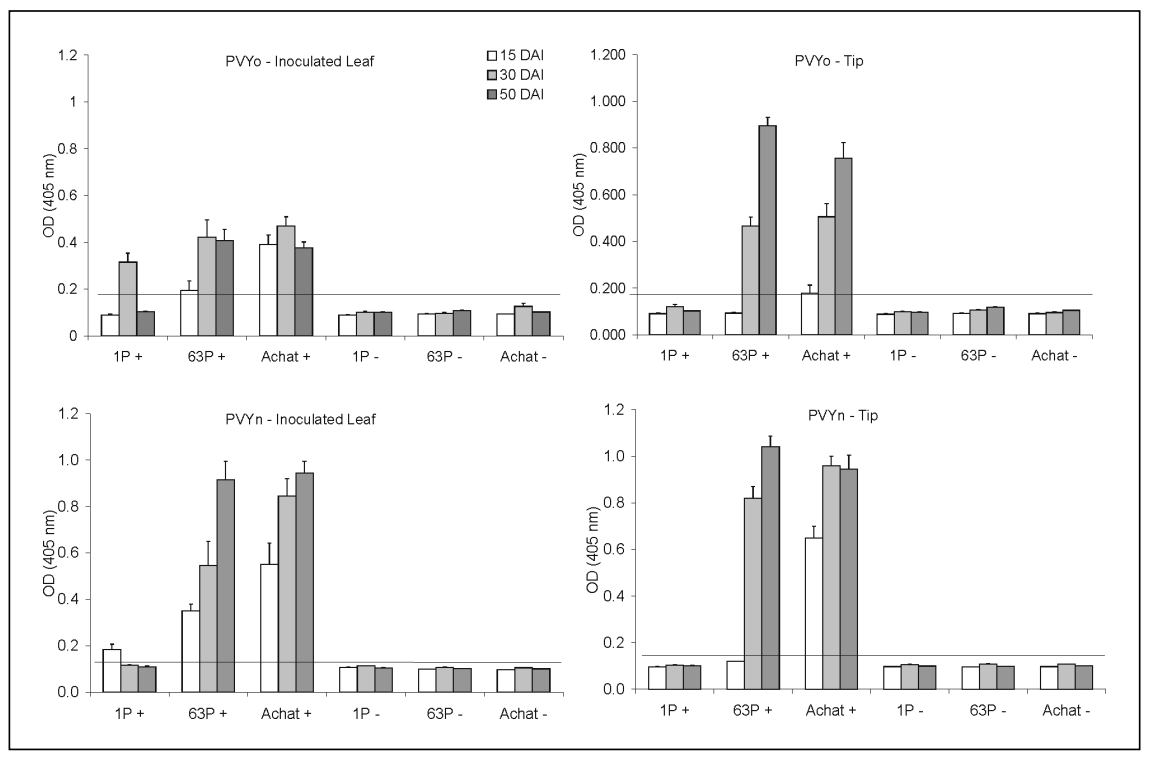

Figure 1. Elisa plate readings (O.D. at $405 \mathrm{~nm}$ ) of leaf samples from clones 1P, 63P and Achat, inoculated (+) or not inoculated (-) at $15 ; 30$ and 50 days after inoculation (DAI). Data is an average of five replications (Error bar: standard error of the mean). Brasília, Embrapa Hortaliças, 2.001.

\section{ACKNOLEDGMENTS}

The authors thank the Brazilian Conselho Nacional de Desenvolvimento Cientifico e Tecnológico (CNPq) for the grants, to the program RHAE Biotecnologia and to the Centro Brasileiro Argentino de Biotecnologia (CBAB).

\section{LITERATURE CITED}

ÁVILA, A.C.; GAMA, M.I.C.S.; NAKASHIMA, J.; BEEK, M.A.. Produção de anti-soro em Elisa Enzyme Linked Immnumosorbent Assay), para detecção de vírus Y da batata em batata. Fitopatologia Brasileira, Brasília, v. 11, n. 2, p. 297, 1986.
CENTRO INTERNACIONAL de la PAPA, Lima, Peru. Control of virus and virus-like diseases of potato and sweet potato. Report of the 3rd Planing Conference. Lima, Peru, 1990. 228 p.

CLARK, M.F.; ADAMS, A.N. Characteristics of the microplate method of enzyme linked immunosorbent assay for the detction of plant viruses. Journal of Genetic Virology, v. 34, p. 475483, 1977.

HULL, R.; DAVIES, J.W. Approaches to nonconventional control of plant virus diseases. Crit. Ver. Plant Sci., v. 11, p. 17-33, 1992.

LINDBO, J.A.; DOUGHERTY, W.G. Untranslatable transcript of the tobacco etch virus coat protein gene sequence can interfere with tobacco etch virus replication in transgenic plants and protoplasts. Virology, v. 189, p. 725-733, 1992. NAGATA INOUE, A.K.; FONSECA, M.E.N.; LOBO, O.T.A.; AVILA, A.C.; MONTE, D.C. Analysis of the nucleotide sequence os the coat protein and 3: untranslated region of two Brazilian Potato Virus Y isolate. Fitopatologia Brasileira, Fortaleza, v. 26, p. 45-52, 2.001.

ROMANO, E.; FERREIRA, A.T.; DUSI, A.N.; PRITE, K.; ÁVILA, A.C.; NISHIJIMA, M.; NASCIMENTO, A.S.; BRAVO-ALMONACID F., MENTABERRY, A.; MONTE, D.; CAMPOS, M.A.; MELO, P.E.; CATTONY, M.K.; TORRES, A.C. Extreme resistance to two brazilian strains of Potato virus Y (PVY) in transgenic potato, cv. Achat, expressing the $\mathrm{PVY}^{\circ}$ coat protein. Horticultura Brasileira, Brasília, v. 19, n. 2, p. 118-122, 2001

VAYDA, M.E.; BELKNAP, W.R. The emergence of transgenic potatoes as commercial products and tools for basic science. Transgenic Research, v. 1, p. 149-163, 1992.

WIJKAMP, I. Virus-vector relationships in the transmission of tospoviruses. Wageningen, The Netherlands, 1995. 143 p. (Ph. D. Thesis). 